\title{
Current Understanding of Epidemiology and Clinical Manifestation of Coronavirus Disease 2019 (COVID-19)
}

\author{
Trenutna saznanja o epidemiologiji i kliničkoj prezentaciji koronavirusne bolesti 2019 \\ (COVID-19) \\ Ljiljana Lukić, Davorka Dušek \\ University Hospital for Infectious Diseases „Dr. Fran Mihaljevic”, Zagreb, Croatia
}

\begin{tabular}{|c|c|}
\hline \multirow{4}{*}{$\begin{array}{l}\text { Keywords: } \\
\text { clinical manifestations } \\
\text { COVID-19 } \\
\text { epidemiology } \\
\text { SARS-CoV-2 }\end{array}$} & Summary \\
\hline & Since it emerged in China in the late 2019, the SARS-CoV-2 virus has spread throughout the world and caused the \\
\hline & newest pandemic. The epidemiological characteristics of the virus and the clinical manifestations of the COVID-19 \\
\hline & disease are currently being studied. The new data is emerging continuously but not yet fully understood. So far, we \\
\hline $\begin{array}{l}\text { Ključne riječi: } \\
\text { kliničke manifestacije } \\
\text { COVID-19 } \\
\text { epidemiologija } \\
\text { SARS-CoV-2 }\end{array}$ & have learned a lot about the virus and the disease but more research is needed as many issues are still being explored. \\
\hline \multicolumn{2}{|l|}{$\begin{array}{l}\text { Primljeno: } 19-07-2020 \\
\text { Received: } 19-07-2020\end{array}$} \\
\hline \multirow[t]{2}{*}{$\begin{array}{l}\text { Prihvaćeno: 25-09-2020 } \\
\text { Accepted: } 25-09-2020\end{array}$} & Sažetak \\
\hline & Otkako se pojavio u Kini krajem 2019. godine, virus SARS-CoV-2 proširio se cijelim svijetom i izazvao najnoviju \\
\hline \multirow{4}{*}{$\begin{array}{l}\triangle \text { Correspondence: } \\
\text { Ljiljana Lukić, MD, } \\
\text { University Hospital for Infectious Diseases } \\
\text { „Dr Fran Mihaljevic”,' Mirogojska 8, } 10000 \text { Zagreb, Croatia } \\
\text { E-mail: Ijlukic@bfm.hr }\end{array}$} & pandemiju. Epidemiološke značajke virusa kao i kliničke manifestacije bolesti COVID-19 su još uvijek predmet \\
\hline & istraživanja. Neprestano dolazimo do novih spoznaja, ali još uvijek ne razumijemo u potpunosti SARS-CoV-2 virus \\
\hline & i bolest koju uzrokuje. Do sada smo velikom brzinom naučili dosta o virusu i COVID-19 bolesti, ali je potrebno još \\
\hline & više istraživanja, jer su mnoga pitanja još uvijek otvorena. \\
\hline
\end{tabular}

\section{Brief History of COVID-19 Pandemic}

The first reports of a new respiratory disease accompanied by pneumonia appeared in December 2019 in the city of Wuhan in the province of Hubei in China. Since the first reports of cases from Wuhan, more than 82,000 coronavirus disease 2019 (COVID-19) cases have been reported in China so far, culminating in March 2020. ${ }^{[1]}$ The World Health Organisation declared COVID-19 pandemic on March 11, 2020. ${ }^{[2]}$ Until now, cases have been reported on all continents except Antarctica, with a total number rising to more than 6 million cases worldwide by June 1, 2020. ${ }^{[1]}$ The first confirmed and laboratory-proven case in Croatia was a young man from Zagreb, who arrived on February 20, 2020 from the Italian province of Lombardy, which has been officially affected by the new Coronavirus epidemic since February 21, 2020. ${ }^{[3]}$

\section{About the Virus}

In late December 2019 in Wuhan, China, a new beta-Coronavirus was confirmed in patients with unknown respiratory viral disease and pneumonia. Meanwhile, the genome sequencing of the Severe Acute Respiratory Syndrome 2 (SARS-CoV-2) virus from a person with COVID-19 showed it is sharing $79.5 \%$ of the sequence with SARS-CoV, while $93.3 \%$ of its genome is identical to the newly identified bat Coronavirus from bats living in the Yunnan Province of southern China. This virus also appears to contain insertions of amino acids in two subunits, S1 and S2, of the virus's spike protein, the feature found in SARS$\mathrm{CoV}-2$, leading to the theory of the zoonotic origin of the virus. ${ }^{[4]}$

Another similar bat coronavirus, known since 2013, shares $96.1 \%$ of its genome with SARS-CoV-2. 
[5] The SARS-CoV-2 has been shown to have the same cell entry receptor, ACE2, as SARS-CoV.$^{[5]}$ Neither of the viruses is a direct ancestor of SARS-CoV-2.

A report of autopsy tissue samples, obtained from 22 patients who had died from COVID-19 reviewing SARS-CoV-2 viral load, detected the highest levels of SARS-CoV-2 copies per cell in the respiratory tract. Furthermore, the virus has been detected in the kidneys, liver, heart, brain, and blood, although in lower viral loads. ${ }^{[6]}$

\section{Transmission Mode}

The complete understanding of the SARS-CoV-2 transmission pathway is still unsolved. An epidemiological investigation in Wuhan at the beginning of the epidemic identified a possible link to the seafood market selling live animals. ${ }^{[1]}$ However, as the epidemic progressed, human-to-human spread became the main transmission mode. It is believed that SARS-CoV-2 is spread by droplets, including coughing, sneezing, and talking, but also by direct mucosal contact with the infected person; infection can occur indirectly via contact with an infected surface. The droplets usually do not travel more than six meters and do not remain in the air. ${ }^{[7]}$ Although one study showed SARS-CoV-2 can remain viable in experimentally produced aerosols for at least three hours, its relevance to the epidemiology of COVID-19 and its clinical implications are not clear. ${ }^{[8]}$ RNA SARS-CoV-2 was detected in blood and stool samples, but the fecal-oral transmission does not appear to be a significant factor in the infection spread. ${ }^{[9]}$ The interval, during which an individual with COVID-19 is contagious, has not yet been fully elucidated. Most data originate from the studies assessing the presence of viral RNA in respiratory and other samples, with positivity persisting on average of 44.9 days (range 8 - 82 days) after the initial occurrence of the symptoms. ${ }^{[10]}$

However, the presence of viral RNA does not necessarily indicate the ability to infect. Viral RNA levels in the upper airway samples appear to be higher after the onset of symptoms, compared to the later stage of the disease. ${ }^{[11]}$ An important factor enabling the virus spread is the transmission by asymptomatic persons. In one report from a nursing facility in the USA, more than half ( 27 of 48 ) of the residents who were asymptomatic at testing, had positive tests for SARS-CoV, with 24 of those becoming symptomatic in the following week, thus contributing to the virus spread. ${ }^{[12]}$

\section{Asymptomatic Infections}

Asymptomatic infections seem to be common but their precise frequency remains to be determined. In a report of a screening program of pregnant women presenting for delivery at two New York hospitals during the pandemic, 29 of 210 asymptomatic women (14\%) were positive for a SARS-CoV-2 RT-PCR test. ${ }^{[13]}$ Nishiura $H$. and colleagues estimated the ratio of asymptomatic individuals, using the information on Japanese evacuated by charter flights from Wuhan to China, is $30.8 \% .{ }^{[14]}$ Transmission of SARS-CoV-2 from asymptomatic subjects (or from subjects within the incubation period) has been described. In an analysis of 157 cases of locally acquired COVID-19 cases in Singapore, estimated is that the transfer during the incubation period is 6.4\%; in such cases, exposures occurred one to three days prior to the symptoms onset. ${ }^{[15]}$ However, the extent to which this occurs remains unknown.

There have been reports of SARS-CoV-2 asymptomatic infection with radiological abnormalities. One such report of 55 patients with asymptomatic infection identified through contact tracing showed that $67 \%$ had CT confirmed pneumonia, prior development of any symptoms. ${ }^{[16]}$

\section{Clinical Manifestation}

\section{Initial Clinical Presentation}

The incubation period is reported to be 3 to 14 days. In a study of 1,099 patients with confirmed symptomatic COVID-19 disease, the mean incubation period was 4 days (interquartile range 2 to 7 days). ${ }^{[17]}$ According to one estimate, as many as $97.5 \%$ of individuals developed fever up to 12.5 days from exposure. ${ }^{[15]}$

A 3-stage classification of COVID-19 disease based on severity has been proposed: Stage I (mild) - early infection, Stage II (moderate) - pulmonary involvement (IIa) without and (IIb) with hypoxia and Stage III (severe) - systemic hyperinflammation, correspond with distinct clinical finding, response to therapy and clinical outcome. ${ }^{[18]}$

Evaluation and management of COVID-19 depends on the disease severity. According to a report of 72,314 cases from China, the course of COVID-19 disease varies from mild ( $81 \%$ of cases) to moderate, requiring hospitalization and monitoring ( $14 \%$ of cases), to severe, requiring intensive treatment (5\% of cases). ${ }^{[19]}$ Mild disease is usually self-limiting with symptoms resolution within two weeks. ${ }^{[19]}$ Patients with moderate or severe COVID-19 are usually hospitalized for observation and supportive care.

To our knowledge, there are no specific clinical features that distinguish COVID-19 from other viral respiratory infections. The largest report from China described the most common symptoms, which were: 
fever $(88.7 \%)$ and cough (67.8\%), general weakness (38.1\%), expectoration (33.7\%), shortness of breath (18.7\%), myalgia and arthralgia (14.9\%), sore throat (13.9\%), headache (13.6\%) and chills (11.5\%), ${ }^{[19]}$ with similar symptoms reported in a study of 5700 patients in New York City Area, USA. ${ }^{[20]}$ However, one study reported fever $>38^{\circ} \mathrm{C}$ at a presentation in only half the patients, ${ }^{[21]}$ while another one in only $31 \%$ of patients. [20] Some cohorts reported around $40 \%$ of patients presenting with gastrointestinal symptoms such are anorexia, nausea, and diarrhoea, while up to $10 \%$ of patients present with gastrointestinal symptoms without respiratory symptoms or fever. ${ }^{[22,23]}$ Lately, reports of smell and taste disorder emerged from Italy. ${ }^{[24]}$ In one survey from Italy of 202 outpatient adults who were diagnosed with mild disease, the alteration of the sense of smell or taste was reported by $64.4 \%$ of the patients. Another Italian study described the occurrence of anosmia and ageusia before the onset of typical COVID-19 symptoms in $11.9 \%$ of the patients; in $3.0 \%$ of patients those were the only symptoms. ${ }^{[25]}$ The clinical condition of some patients who initially have mild symptoms may worsen within a week. ${ }^{[26]}$ Based on several studies from China of the patients hospitalized in Wuhan for COVID-19 and pneumonia, dyspnea occurred on average on the fifth day after the onset of symptoms, while the median from the onset of symptoms to hospitalization was 7 days. ${ }^{[15,27]}$

TABLE 1. RISK FACTORS FOR SEVERE COVID- $19^{[17,19,21,26,27,43]}$

TABLICA 1. RIZIČNI FAKTORI ZA TEŠKI OBLIK BOLESTI COVID-19 $9^{[17,19,21,26,27,43]}$

\begin{tabular}{|l|}
\hline Age $>65$ years \\
\hline Pre-existing pulmonary disease \\
\hline Chronic kidney disease \\
\hline Diabetes mellitus \\
\hline History of hypertension \\
\hline History of cardiovascular disease \\
\hline Cancer \\
\hline Obesity (BMI $\geq 30)$ \\
\hline Smoking \\
\hline $\begin{array}{l}\text { Immunocompromised people (e.g. use of biologics, history of } \\
\text { transplant or other immunosuppression, HIV) }\end{array}$ \\
\hline
\end{tabular}

\section{Complications}

Acute respiratory distress syndrome (ARDS) is a major complication in patients with severe disease and may manifest soon after the development of dyspnea. In reports from China, ARDS developed in $20 \%$ of hospitalized patients in the interval of $8-12$ days after the symptoms onset; $12.3 \%$ of patients were on mechanical ventilation. ${ }^{[21,26]}$ Similar trend was described in studies in the USA $(14.2 \%$ hospitalized patients required treatment in ICU, $12.2 \%$ mechanical ventilation, while $3.2 \%$ were treated with hemodialysis). ${ }^{[20]}$

A group of researchers described postmortem findings from 10 consecutive patients with confirmed COVID-19 as showing acute and organizing diffuse alveolar damage as the primary histopathologic finding and the leading cause of death among patients, regardless of treatment with invasive ventilation. ${ }^{[28]}$ Age over 65 years, diabetes, and arterial hypertension were more common in patients with ARDS. ${ }^{[27]}$

Other common complications of COVID-19 include respiratory failure, sepsis, acute myocardial injury, defined by elevated troponin levels, cardiac decompensation, renal failure, and hypoxic encephalopathy. These complications were more common in patients with comorbidities, but even after adjustment for comorbidities, they increased the risk of death of COVID-19 in previously healthy individuals..$^{[29,30,31]}$

The most common abnormal laboratory parameter is lymphopenia, followed by leukopenia and leukocytosis. Elevated levels of LDH, ferritin, and AST are common. On admission, many patients with pneumonia have normal serum procalcitonin levels; however, individuals requiring admission to the intensive care unit are more likely to have elevated procalcitonin. ${ }^{[26]}$ High levels of D-dimer and more severe lymphopenia were present in patients with higher mortality ${ }^{[32]}$

Mehta and colleagues emphasized the growing evidence suggesting a subgroup of patients with severe COVID-19 might have cytokine storm syndrome. ${ }^{[33]} \mathrm{In}$ a cohort from two New York hospitals, the researchers estimated inflammation of the 257 (22\%) patients who required intensive care, finding a $10 \%$ increase in risk for death with every $10 \%$ increase of IL-6 or D-dimer concentration. ${ }^{[34]}$ Additionally, high blood levels of cytokines and chemokines have been detected in patients with COVID-19, including: IL1- $\beta$, IL1RA, IL7, IL8, IL9, IL10, basic FGF2, GCSF, GMCSF, IFN $\gamma$, IP10, MCP1, MIP1 $\alpha$, MIP1 $\beta$, PDGFB, TNF $\alpha$, and VEGFA. ${ }^{[35]}$

\section{Hypercoagulability and Cardiovascular Manifestations}

COVID-19 has been associated with a hypercoagulable state with an increased risk of venous thromboembolism. ${ }^{[36]}$ In one observational study, the authors compared the occurrence of thromboembolic events between non-COVID-19 ARDS and COVID-19 ARDS patients. They found clinically relevant thrombotic complications in 64 of 150 patients with COVID-19, most commonly pulmonary embolisms (16.7\%). In comparison with 145 non-COVID-19 ARDS patients, 
COVID-19 ARDS patients had a higher risk of developing pulmonary embolisms ( $11.7 \%$ versus $2.1 \%)$. Additionally, in almost all (96.6\%) COVID-19 patients receiving continuous renal replacement therapy, a circuit clotting was noted. Most patients (>95\%) had elevated D-dimer and fibrinogen. Other coagulation parameters such are Von Willebrand (vWF) activity, vWF antigen and FVIII were increased, including positive lupus anticoagulant. ${ }^{[37]}$ Another possible manifestation of hypercoagulability is a stroke, according to a case series of five young patients with confirmed SARS-CoV-infection presenting a large vessel stroke $\mathrm{e}^{[38]}$ Coagulopathy has been reported as one possible manifestation with poor prognosis. In a retrospective series of 183 consecutive patients, the authors reported that $71.4 \%$ of non-survivors met the criteria of disseminated intravascular coagulation (DIC), while only $0.6 \%$ of survivors did. ${ }^{[39]}$ In support of that, another report from Thang et al. reported decreased 28-day mortality in patients with severe COVID-19 that present with coagulopathy if treated with low molecular weight heparin (LMWH) administered for 7 days or longer. ${ }^{[40]}$ Postmortem study of lungs from patients who died of confirmed COVID-19 and lungs obtained during autopsy from patients who died from ARDS due to H1N1 influenza in 2009, showed severe endothelial injury, widespread vascular thrombosis with microangiopathy and occlusion of alveolar capillaries and significant new vessel growth. ${ }^{[41]}$

The incidence of cardiovascular manifestations, such as myocardial injury, in COVID-19 patients seems to be high as well. Some claim this is likely due to the systemic inflammatory response and immune system disorders while the disease progresses. ${ }^{[42]}$ In addition, myocardial damage and fulminant myocarditis have been described. ${ }^{[21,43]}$ Another group that reviewed fatal cases reported cardiac arrest or malignant arrhythmia listed as the cause of death for over $10 \%$ of cases, while some form of arrhythmia present in 60\% of COVID-19 patients who died. ${ }^{[44]}$ Additionally, a case of acute cardiac injury with proven low-grade myocardial inflammation and viral particles in the myocardium has been proven via endomyocardial biopsy. ${ }^{[45]}$

\section{Clinical Outcomes}

According to the largest report from China, the case fatality rate was about $2.3 \%$, and in critically ill patients as high as $49.0 \%,{ }^{[30]}$ ranging from $5.8 \%$ in $\mathrm{Wu}-$ han to $0.7 \%$ in the rest of China. ${ }^{[46]}$ In the peak time of the COVID-19 epidemic in Italy, $12 \%$ of all detected cases and $16 \%$ of all hospitalized patients were admitted to the intensive care unit with an estimated case fatality rate of $7.2 \%$ in the peak of the epidemics. ${ }^{[31,47]}$
Around the same time, South Korea reported the estimated case fatality rate of $0.9 \%^{[48]}$, which may be due to demographics. A significant proportion of deaths in Italy is over 90 years of age, with an age-specific case fatality rate of $22.7 \%$, compared with China, which does not stratify over 90 years of age. ${ }^{[36]}$

In Italy, the mortality rate of patients admitted to intensive care units was $26 \% \cdot{ }^{[31]}$ On the other hand, in a study of 2634 hospitalized patients from New York City, of $12 \%$ patients who received invasive mechanical ventilation, $88 \%$ died. ${ }^{[20]}$

In patients with comorbidities, the mortality rate is significantly higher - $10.5 \%$ for cardiovascular diseases, $7.3 \%$ for diabetes, $6.3 \%$ for chronic respiratory diseases, $6.0 \%$ for hypertension, and $5.6 \%$ for cancer ${ }^{[27]}$ In one report from Italy, of 355 patients who died with COVID 19, the mean value of chronic diseases was 2.7 , while only three patients were previously healthy. ${ }^{[47]}$ These outcomes vary in affected countries, although a mild form of the disease predominates everywhere. According to several studies concurrent with ACEI/ $\mathrm{ARB}$, the therapy is not a risk factor for the development of severe COVID-19 and does not increase the risk of death. ${ }^{[49,50]}$

\section{REFERENCES}

${ }^{[1]}$ World Health Organisation. WHO COVID-2019 situation reports. [Internet]. Available at: https://www.who.int/emergencies/diseases/novel-coronavirus-2019/situation-reports (Accessed on July 1, 2020)

${ }^{[2]}$ World Health Organisation. WHO Director-General's opening remarks at the media briefing on COVID-19 - 11 March 2020. [Internet]. Available at: https://www.who.int/dg/speeches/detail/who-director-general-s-opening-remarks-at-themedia-briefing-on-covid-19---11-march-2020. (Accessed on May 21, 2020)

${ }^{[3]}$ Croatian Institute of Public Health. Statement on the first case of COVID-19. [Internet]. Available at: https://www.hzjz.hr/ priopcenja-mediji/covid-19-priopcenje-prvog-slucaja/ (Accessed on May 21, 2020)

${ }^{[4]}$ Zhou H, Chen X, Hu T, et al. A novel bat coronavirus closely related to SARS-CoV-2 contains natural insertions at the S1/S2 cleavage site of the spike protein. Curr Biol. 2020;30(11):21962203.e3.

${ }^{[5]}$ Zhou P, Yang X, Wang X, et al.A pneumonia outbreak associated with a new coronavirus of probable bat origin. Nature2020;579:270-273.

${ }^{[6]}$ Puelles VG, Lütgehetmann M, Lindenmeyer MT, et al. Multiorgan and Renal Tropism of SARS-CoV-2. N Engl J Med. 2020;383(6):590-592

${ }^{[7]}$ Coronavirus disease 2019 (COVID-19). [Internet]. Available at: https://www.uptodate.com/contents/coronavirus-disease-2019-covid-19 (Accessed on May 21, 2020.)

${ }^{[8]}$ van Doremalen N, Bushmaker T, Morris DH, et al. Aerosol and surface stability of SARS-CoV-2 as compared with SARSCoV-1. N Engl J Med. 2020;382(16):1564-7. 
${ }^{[9]}$ Wang W, Xu Y, Gao R, et al. Detection of SARS-CoV-2 in different types of clinical specimens. JAMA. 2020;323(18):18431844.

${ }^{[10]}$ KDCA. Findings from investigation and analysis of re-positive cases. Printed ed. May 19., 2020. Available at: https://www.cdc. go.kr/board/board.es?mid=a30402000000\&bid=0030 (Accessed on June 1,2020)

${ }^{[11]}$ To KK, Tsang OT, Leung WS, et al. Temporal profiles of viral load in posterior oropharyngeal saliva samples and serum antibody responses during infection by SARS-CoV-2: an observational cohort study. Lancet Infect Dis. 2020;20(5):565-574.

${ }^{[12]}$ Arons MM, Hatfield KM, Reddy SC, et al. Presymptomatic SARS-CoV-2 Infections and Transmission in a Skilled Nursing Facility.N Engl J Med. 2020;382(22):2081-2090.

${ }^{[13]}$ Sutton D, Fuchs K, D'Alton M, Goffman D. Universal Screening for SARS-CoV-2 in Women Admitted for Delivery. N Engl J Med. 2020;382(22):2163-2164.

${ }^{[14]}$ Nishiura H, Kobayashi T, Miyama T, et al. Estimation of the asymptomatic ratio of novel coronavirus infections (COVID-19). Int J Infect Dis. 2020;94:154-5.

${ }^{[15]}$ Lauer SA, Grantz KH, Qiang B, et al. The incubation period of coronavirus disease 2019 (COVID-19) from publicly reported confirmed cases: estimation and application. Ann Intern Med. 2020;172(9):577-582.

${ }^{[16]}$ Mizumoto K, Kagaya K, Zarebski A, Chowell G. Estimating the asymptomatic proportion of coronavirus disease 2019 (COVID-19) cases on board the Diamond Princess cruise ship, Yokohama, Japan, 2020. Euro Surveill. 2020;25(10):2000180.

${ }^{[17]}$ Guan WJ, Ni ZY, Hu Y, et al. China Medical Treatment Expert Group for Covid-19. Clinical Characteristics of Coronavirus Disease 2019 in China. N Engl J Med. 2020;382(18):1708-20.

${ }^{[18]}$ Siddiqi HK, Mehra MR. COVID-19 illness in native and immunosuppressed states: A clinical-therapeutic staging proposal. J Heart Lung Transplant. 2020;39(5):405-407.

${ }^{[19]} \mathrm{Wu}$ Z, McGoogan JM. Characteristics of and important lessons from the coronavirus disease 2019 (COVID-19) outbreak in China: summary of a report of 72314 cases from the Chinese Center for Disease Control and Prevention. JAMA. 2020;323(13):1239-1242.

${ }^{[20]}$ Richardson S, Hirsch JS, Narasimhan M, et al.Presenting Characteristics, Comorbidities, and Outcomes Among 5700 Patients Hospitalized With COVID-19 in the New York City Area.JAMA. 2020;323(20):2052-2059.

${ }^{[21]}$ Zhou F, Yu T, Du R, et al. Clinical course and risk factors for mortality of adult inpatients with COVID-19 in Wuhan, China: a retrospective cohort study. Lancet. 2020;395(10229):10541062.

${ }^{[22]}$ Pan L, Mu M, Yang P, et al. Clinical Characteristics of COVID-19 Patients With Digestive Symptoms in Hubei, China: A Descriptive, Cross-Sectional, Multicenter Study. Am J Gastroenterol. 2020;115(5):766-773.

${ }^{[23]}$ Zhang JJ,Dong X,Cao YY, et al.Clinical characteristics of 140 patients infected with SARS-CoV-2 in Wuhan, China. Allergy. 2020;75(7):1730-1741.

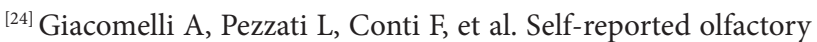
and taste disorders in SARS-CoV-2 patients: a cross-sectional study. Clin Infect Dis. 2020;71(15):889-890.

${ }^{[25]}$ Spinato G, Fabbris C, Polesel J, et al. Alterations in smell or taste in mildly symptomatic outpatients with SARS-CoV-2 infection.JAMA. 2020;323(20):2089-2090.
${ }^{[26]}$ Wang D, Hu B, Hu C, et al. Clinical characteristics of 138 hospitalized patients with 2019 novel coronavirus-infected pneumonia in Wuhan, China. JAMA. 2020;323(11):1061-1069.

${ }^{[27]}$ Huang C,Wang Y,Li X, et al. Clinical features of patients infected with 2019 novel coronavirus in Wuhan, China. Lancet2020;395:497-506.

${ }^{[28]}$ Schaller T, Hirschbühl K, Burkhardt K, et al. Postmortem Examination of Patients With COVID-19. JAMA. 2020; 323(24):2518-2520.

${ }^{[29]}$ Wu C, Chen X, Cai Y, et al. Risk factors associated with acute respiratory distress syndrome and death in patients with coronavirus disease 2019. pneumonia in Wuhan, China. JAMA Intern Med. 2020 Jul 1;180(7):934-943.

${ }^{[30]}$ Chen T, Wu D, Chen H, et al. Clinical characteristics of 113 deceased patients with coronavirus disease 2019: retrospective study. BMJ. 2020 Mar 26;368:m1091.

${ }^{[31]}$ Grasselli G, Zangrillo A, Zanella A, et al. Baseline characteristics and outcomes of 1591 patients infected with SARS-CoV-2 admitted to ICUs of the Lombardy Region, Italy. JAMA. 2020; 323(16):1574-1581.

${ }^{[32]}$ Chen N, Zhou M, Dong X, et al. Epidemiological and clinical characteristics of 99 cases of 2019 novel coronavirus pneumonia in Wuhan, China: a descriptive study. Lancet. 2020;395(10223):507-513.

${ }^{[33]}$ Mehta P, McAuley DF, Brown M, et al. COVID-19: consider cytokine storm syndromes and immunosuppression. Lancet. 2020;395(10229):1033-1034.

${ }^{[34]}$ Cummings MJ, Baldwin MR, Abrams D, et al. Epidemiology, clinical course, and outcomes of critically ill adults with COVID-19 in New York City: a prospective cohort study. Lancet. 2020;395(10239):1763-1770.

${ }^{[35]}$ Rothan HA, Byrareddy SN. The epidemiology and pathogenesis of coronavirus disease (COVID-19) outbreak. J Autoimmun. 2020;109:102433.

${ }^{[36]}$ Danzi GB, Loffi M, Galeazzi G, Gherbesi E. Acute pulmonary embolism and COVID-19 pneumonia: a random association? Eur Heart J. 2020;41(19):1858.

${ }^{[37]}$ Helms J, Tacquard C, Severac F, et al. High risk of thrombosis in patients with severe SARS-CoV-2 infection: a multicenter prospective cohort study. Intensive Care Med. 2020;46(6):1089-1098.

${ }^{[38]}$ Oxley TJ, Mocco J, Majidi S, et al. Large-Vessel Stroke as a Presenting Feature of Covid-19 in the Young.N Engl J Med. 2020; 382(20):e60.

${ }^{[39]}$ Tang N, Li D, Wang X, Sun Z. Abnormal coagulation parameters are associated with poor prognosis in patients with novel coronavirus pneumonia. J Thromb Haemost. 2020;18(4):844847.

${ }^{[40]}$ Tang N, Bai H, Chen X, Gong J, Li D, Sun Z. Anticoagulant treatment is associated with decreased mortality in severe coronavirus disease 2019 patients with coagulopathy. J Thromb Haemost. 2020;18(5):1094-1099.

${ }^{[41]}$ Ackermann M, Verleden SE, Kuehnel M, et al. Pulmonary Vascular Endothelialitis, Thrombosis, and Angiogenesis in Covid-19. N Engl J Med. 2020;383(2):120-128.

${ }^{[42]}$ Zheng YY, Ma YT, Zhang JY, Xie X. COVID-19 and the cardiovascular system. Nat Rev Cardiol. 2020;17(5):259-260.

${ }^{[43]}$ Ruan Q, Yang K, Wang W, Jiang L, Song J. Clinical predictors of mortality due to COVID-19 based on an analysis of data of 150 patients from Wuhan, China. Intensive Care Med. 2020;46(5):846-848. 
${ }^{[44]} \mathrm{Du}$ Y, Tu L, Zhu P, et al. Clinical Features of 85 Fatal Cases of COVID-19 from Wuhan. A Retrospective Observational Study. Am J Respir Crit Care Med. 2020;201(11):1372-1379.

${ }^{[45]}$ Tavazzi G, Pellegrini C, Maurelli M, et al. Myocardial localization of coronavirus in COVID-19 cardiogenic shock. Eur J Heart Fail. 2020;22(5):911-915.

${ }^{[46]}$ Li D, Jin M, Bao P, Zhao W, Zhang S. Clinical Characteristics and Results of Semen Tests Among Men With Coronavirus Disease 2019. JAMA Netw Open. 2020;3(5):e208292.

${ }^{[47]}$ Onder G, Rezza G, Brusaferro S. Case-fatality rate and characteristics of patients dying in relation to COVID-19 in Italy. JAMA. 2020;323(18):1775-1776.
${ }^{[48]}$ KDCA. Updates on COVID-19 in Korea. March 14, 2020. [Internet] Available at: https://www.cdc.go.kr/board/board.es$? \mathrm{mid}=\mathrm{a} 30402000000 \& \mathrm{bid}=0030$. (Accessed on May 21, 2020.)

${ }^{[49]}$ Zhang P, Zhu L, Cai J, et al. Association of Inpatient Use of Angiotensin Converting Enzyme Inhibitors and Angiotensin II Receptor Blockers with Mortality Among Patients With Hypertension Hospitalized With COVID-19. Circ Res. 2020; 126 (12): 1671-1681.

${ }^{[50]}$ Li J, Wang X, Chen J, Zhang H, Deng A. Association of Renin-Angiotensin System Inhibitors With Severity or Risk of Death in Patients With Hypertension Hospitalized for Coronavirus Disease 2019 (COVID-19) Infection in Wuhan, China. JAMA Cardiol. 2020;5(7):825-830. 